\title{
The Effect of Organic Substrates Application on the Amylolytic Activity of Urban Soils
}

\author{
Urszula Wydro' ${ }^{1}$, Elżbieta Wołejko' ${ }^{1}$, Agata Jabłońska-Trypuć1, Andrzej Butarewicz'1, \\ Tadeusz Łoboda' \\ 1 Bialystok University of Technology, Department of Chemistry, Biology and Biotechnology, Wiejska 45E, \\ 15-351 Białystok. Poland \\ * Corresponding author's e-mail: u.wydro@pb.edu.pl
}

\begin{abstract}
The aim of this work was to investigate the influence of fresh and thermally treated sewage sludge on the amylolytical activity of the urban soils. Two experimental areas on the lawns along the main roads of Bialystok were prepared in 2011 and 2015. The factors taken into account in the experiment involved: the type of sewage sludge (mechanically dewatered - SS and thermally dried "Granbial" - G), three doses of sewage sludge ( 0 - control; 14.5 and $29 \mathrm{t} \mathrm{DM} / \mathrm{ha}$ ) and two grass mixtures (Eko and Roadside). The number of amylolytic bacteria in grass mixtures and rhizosphere and amylase activity in soil were monitored twice during 2011 and 2012 vegetation season (in July and October). The main properties of soil (soil pH, granulometric composition, total organic carbon - TOC, available phosphorus and total nitrogen content) after the application of organic substrates were also analysed. Addition of the dewatered sewage sludge to soil resulted in an increase in the number of amylolytic bacteria (from 7.4 to $18.8 \cdot 10^{6} \mathrm{cfu} / \mathrm{g} \mathrm{DM}$ ) in July, while in the soil treatment with thermally dried sludge, the increased number of the bacteria (from 11.03 to $44.68 \cdot 10^{6} \mathrm{cfu} / \mathrm{g} \mathrm{DM}$ ) was observed in October. The amylases activity in the soil treated with SS exhibited the highest average value in July $(2.11 \mathrm{mg} \mathrm{Glc} / \mathrm{g} \mathrm{DM} \cdot 24 \mathrm{~h})$, while in the soil treated with "Granbial", it was stable in studied period (from 1.65 to $2.18 \mathrm{mg} \mathrm{Glc/g} \mathrm{DM} \cdot 24 \mathrm{~h}$ ).
\end{abstract}

Keywords: sewage sludge, rhizosphere, urban soil, amylases activity, amylolytic bacteria

\section{INTRODUCTION}

The urban soils in Poland are the least studied group of soils [Niedbała et al 2010]. According to Greinert [2000], urban soils are easily degraded because of a low content of humus and organic matter, low water capacity and a small amount of nutrients. The structure of these soils is not uniform and often is made of construction waste, such as rubble, brick and steel. Furthermore, soil has a compact structure as a result of using heavy equipment, which disturbs the air-water relations. In addition, the urban area located along communication routes is exposed to the pollution from transport. Wysocki and Stawicka [2005] have reported that the mechanical and chemical transformation of soil in the urban area causes the negative changes of its biological activity, which subsequently determines a proper biocenoses functioning. The transport contaminants can be harmful to soil microorganisms and interfere with their mutual relation [Bach and Frazik-Adamczyk 2005].

Lawns, as a basic element of green areas in cities, are the simplest and most natural coverage of soil surface. Grasses play an important role as a pioneer species in setting difficult areas. Lawns are essential for the protection and stabilization of soil, air purification, pollution absorption and microclimate improvement [Grejnert 2000, Wolski et al 2006]. Due to their function it is necessary to ensure proper quality of soil and growth of grasses.

The progressing urbanization has caused an increase in the amount of domestic and industrial wastes such as sewage sludge. The most common way for the management of this biosolid is its environmental recycling as a fertilizer or reclama- 
tion substrate. Sewage sludges are rich in organic matter, macro- such as nitrogen, phosphorus and microelements and can improve the physical, chemical and biological properties of soil [Jamali 2008, Jezierska-Tyś and Frąc 2008, Singh and Agrawal 2008, Sanches-Monedero 2004, Siuta 2003]. The above-mentioned properties support the use of sludge in the degraded soil reclamation in urban space, including the formation of lawns.

The amylolytic bacteria hydrolyze starch and glycogen by using amylases such as: $\alpha$-amylase and $\beta$-amylase. The degradation products (i.e. glucose) are utilized by microorganisms as a source of carbon and energy and by plants as a source of nutrients [Kucharski et al 2000].

The aim of this work was to investigate the impact of unprocessed and thermally treated sewage sludge on the amylolytical soil activity, expressed as the number of amylolytic bacteria and soil amylases activity. Subsequently, the obtained results were compared with selected physicochemical properties of the soil.

\section{MATERIAL AND METHODS}

Two field experiments were prepared on the two lawns along the main roads of Białystok, (ul. Hetmańska and Popiełuszki)where two types of organic substrates were applied. The first experi- ment was established in 2010, whereas the second in 2014. In each study, one experimental area of $90 \mathrm{~m}^{2}$ was divided into 18 plots, $5 \mathrm{~m}^{2}$ each.

The stabilized mechanical dewatered municipal sewage sludge from the Municipal Wastewater Treatment Plant in Sokółka (SS) and organic fertilizer "Granbial" produced from the sewage sludge during thermal processing (at $200^{\circ} \mathrm{C}$ ) in a Wastewater Treatment plant in Białystok $(G)$ were used. In autumn 2010 and 2014, the studied areas were fertilized with municipal sludge and "Granbial" with 0 (C - control), 14.5 and $29 \mathrm{t}$ $\mathrm{DM} /$ ha, respectively. The doses of sewage sludge were established according to the Regulation of Ministry of Environment [Directive of...2015], where the maximum sludge dose for two-year use for non-agricultural land reclamation does not exceed $30 \mathrm{t}$ of dry matter/ha. The applied substrates were eligible for use in non-agricultural land reclamation in accordance with the Polish regulations [Directive of...2015]. The values of the studied parameters in soils and the substrates characteristics before starting the experiment are presented in Table 1 and 2.

In spring 2011 and 2015, two mixtures of lawn grasses were sown on the prepared plots, i.e. Eko from Nieznanice Plant Breeding Station (M1) which included $30 \%$ of Lolium perenne cv. Niga, $15 \%$ of Poa pratensis cv. Amason, $22.6 \%$ of Festuca rubra cv. Adio and $32.4 \%$

Table 1. Selected physicochemical properties of the soils in the research plots at ul. Hetmańska and Popiełuszki, taken before the foundation of experiments I and II

\begin{tabular}{|c|c|c|c|c|c|c|c|c|c|c|}
\hline \multirow{2}{*}{ Experiment } & \multirow[t]{2}{*}{ Location } & $\mathrm{pH}$ & $\begin{array}{c}\text { Soil } \\
\text { category }\end{array}$ & $P$ & $\mathrm{Cd}$ & $\mathrm{Cr}$ & $\mathrm{Cu}$ & $\mathrm{Ni}$ & $\mathrm{Pb}$ & $\mathrm{Zn}$ \\
\hline & & - & - & $\mathrm{mgP}_{2} \mathrm{O}_{5} / 100 \mathrm{~g}$ & \multicolumn{6}{|c|}{$\mathrm{mg} / \mathrm{kg} \mathrm{DM}$} \\
\hline \multirow{2}{*}{ I } & Hetmańska & 7.9 & light & 7.3 & $<0.5$ & 10.9 & 9.5 & 4.5 & 12.4 & 40.9 \\
\hline & Popiełuszki & 7.6 & light & 22.0 & 1.7 & 13.1 & 17.9 & 5.9 & 26.5 & 82.9 \\
\hline \multirow{2}{*}{ II } & Hetmańska & 8.1 & light & 5.7 & 0.5 & 12.1 & 16.7 & 6.3 & 7.5 & 50.8 \\
\hline & Popiełuszki & 7.7 & light & 20.7 & 0.6 & 11.5 & 26.3 & 8.5 & 5.6 & 74.4 \\
\hline \multicolumn{5}{|c|}{$\begin{array}{l}\text { Limit value in the application of sludge to land reclamation for non- } \\
\text { agricultural purposes }\end{array}$} & 3.0 & 100 & 50 & 30 & 50 & 150 \\
\hline
\end{tabular}

Table 2. Characteristics of the municipal sewage sludge from the sewage treatment plants in Sokółka and "Granbial" from Wastewater Treatment in Białystok used in experiments

\begin{tabular}{|c|c|c|c|c|c|c|c|c|c|c|c|c|c|c|}
\hline $\begin{array}{c}\text { Type of } \\
\text { organic } \\
\text { substrate }\end{array}$ & $\mathrm{pH}$ & $\begin{array}{c}\text { Dry } \\
\text { matter }\end{array}$ & $\begin{array}{c}\text { Organic } \\
\text { substance }\end{array}$ & $\mathrm{N}$ & $\mathrm{P}$ & $\mathrm{N}-\mathrm{NH}_{3}$ & $\mathrm{Ca}$ & $\mathrm{Mg}$ & $\mathrm{Cd}$ & $\mathrm{Cr}$ & $\mathrm{Cu}$ & $\mathrm{Ni}$ & $\mathrm{Pb}$ & $\mathrm{Zn}$ \\
\hline $\begin{array}{c}\text { Sewage } \\
\text { sludge (SS) }\end{array}$ & 6.7 & 19.3 & 58.4 & 3.99 & 2.73 & 0.14 & 5.51 & 0.66 & $<0.5$ & 58.0 & 194 & 22.0 & 23.5 & 1459 \\
\hline $\begin{array}{c}\text { "Granbial" } \\
\text { (G) }\end{array}$ & 8.2 & 81.7 & 56.9 & 4.63 & 3.26 & 0.18 & 3.79 & 0.57 & $<1.25$ & 76.6 & 198 & 30.1 & 26.0 & 1045 \\
\hline
\end{tabular}


of Festuca rubra cv. Nimba, and grass mixture Roadside from Barenbrug (M2) which included $32 \%$ of Lolium perenne cv. Barmedia, $5 \%$ of Poa pratensis cv. Baron, $52 \%$ of Festuca rubra rubra cv. Barustic, 5\% of Festuca rubra commutata cv. Bardiva (BE) and 6\% of Festuca rubra commutata cv. Bardiva (NL).

General procedures regarding the main experiment are shown in Table 3.

\section{Amylolytic activity analyses}

The soil amylolytic activity after organic substrates application was assessed by determining the number of amylolytic bacteria in rhisosphere and soil amylase activity. Fresh samples of grass mixture roots with the soil for a number of amylolitic bacteria analyses and the soil from a depth of $0-20 \mathrm{~cm}$ for the analysis of the amylases activity were collected twice, as it was described in Table 3.

The number of amylolytic bacteria was determined according to the method described by Rodina [1968] on the medium with $2 \%$ of starch. The incubation of microorganisms was carried out at $27^{\circ} \mathrm{C}$ for $96 \mathrm{~h}$. After the incubation time, the colonies grown in Petri dishes were covered by Lugol solution. For the estimation of amylolytic bacteria, the number colonies surrounded with yellow zone were counted. The mean number of colonies was expressed as cfu (colonyforming unit) per $1 \mathrm{~g}$ dry mater of soil and roots (cfu/g DM).

The soil amylases activity was determined with the method based on the analysis of reducing sugars amount produced after the enzymatic hydrolysis of starch. The soil samples were incubated with $1 \%$ starch solution in acetate buffer $(\mathrm{pH}$ 5.5) for $24 \mathrm{~h}$ at $50^{\circ} \mathrm{C}$. The amount of reducing sugars produced, expressed in $\mathrm{mg}$ of released glucose (Glc) was determined with the colorimetric method described by Merci and Schinner [2005] for the invertase activity.

\section{Physicochemical analysis}

The granulometric composition of soil was analyzed by means of Analysette 22 NanoTec Plus (Fritsch) analyser. The values of $\mathrm{pH}$ in the soil samples taken from a depth of 0-20 cm were determined with the potentiometric method in a soil suspension and distilled water in the ratio of 1:2.5. The total nitrogen was measured by using Kjeldahl method based on wet oxidation of organic matter using $\mathrm{H}_{2} \mathrm{SO}_{4}$ and conversion of organic nitrogen to the ammonium form on the Vapodest 50s Analyzer (Gerhardt). The available phosphorus (expressed as $\mathrm{P}_{2} \mathrm{O}_{5}$ ) was determined by Egner-Riehm method in 0.04 solution of calcium lactate. The amount of available phosphorus was determined by UV-vis spectrophotometry Hach Lange DR 5000. The organic carbon (TOC) content was measured using Analytik Jena TOC multi NC analyzer.

\section{Statistical analysis}

The basic statistics (minimal and maximal values, median, means and standard deviation) for the studied physical and chemical parameters were calculated. In order to test the effects of the experimental factors (type and dose of organic substrates, sampling time, grass mixture) in the variables analyzed, the multi-way analysis of variance MANOVA with interaction term was performed. In the case of significant F-tests, the differences between group means were carried out by the Tukey post-hoc test at $\alpha=0.05$. The correlation between the characteristics was calculated using Pearson correlation (with the level of significance established at $\mathrm{p}<0.05$ ). The computation and graphs were done by means of the Statistica 13.0 software.

Table 3. Scheme of experiment I and II

\begin{tabular}{|c|l|l|l|}
\hline \multirow{2}{*}{ Year of study } & Type and dose of sewage sludge & \multicolumn{1}{|c|}{ Mixture of grasses } & Sampling time \\
\hline \multirow{2}{*}{2011} & $\begin{array}{l}\text { SS1 - mechanical dewatered, } \\
\text { 14.5 t DM/ha }\end{array}$ & M1 - Eko & M2 - Roadside \\
\cline { 2 - 3 } & $\begin{array}{l}\text { SS2 - mechanical dewatered, } 29 \\
\text { t DM/ha }\end{array}$ & M1 - Eko & M2 - Roadside \\
\cline { 2 - 3 } & $\begin{array}{l}\text { G1 - thermally dried } \\
\text { "Granbial",14.5 t DM/ha }\end{array}$ & M1 - Eko & M2 - Roadside \\
\cline { 2 - 3 } 2014 & $\begin{array}{l}\text { G2 - thermally dried "Granbial", 29 } \\
\text { t DM/ha }\end{array}$ & M1 - Eko & M2 - Roadside \\
\cline { 2 - 3 } & &
\end{tabular}




\section{RESULT AND DISCUSSION}

The granulometric composition of the studied soils is shown in Table 4. Sand was the dominant fraction in the soils and its amount ranged from 53 to $70 \%$, while the silt content was from 21 to $38 \%$ and clay - from 5 to $14 \%$. The $\mathrm{pH}$ values measured in water for the samples collected in July ranged from 7.1 (for soil G2 -treatment "Granbial" in dose $29 \mathrm{t} \mathrm{DM} /$ ha and M2-grass mixture Roadside) to 7.7 (soil with SS1 and M1) (Figure 1 A-B). Moreover, in October, the $\mathrm{pH}$ values in soil were similar to those in July and were from 7.1 to 7.8 for control with M2 and SS1 with M1, respectively.

Urban soils usually are neutral or alkaline. This is due to the presence of alkaline dusts, contaminants and limestone construction materials [Grejnert 2000]. An increase of soil $\mathrm{pH}$ has been reported also after sewage sludge fertilization, which was related to the use of calcium compounds for the sludge stabilization and hygenization [Singh and Agrawal 2008, Szymków and Świtecka 2013].

The average total organic carbon (TOC) contents in soil after treatment with sewage sludge and "Granbial" fertilizer are shown in Figures 1 C-D. The highest average TOC values in the soil collected in July were observed for the plots with "Granbial" in the dose $29 \mathrm{t} \mathrm{DM} /$ ha with Eko grass mixture (G2 with M2) and was 3.22\% DM, while the lowest was found for control with M1 (1.86\% DM). In the soil samples collected in October, the obtained results indicated that an average content of TOC decreased and ranged from 1.47 to $2.67 \%$ DM from the plots treated using SS1 with M2 and G2 with M1, respectively). The average total content of nitrogen in July ranged from $0.22 \% \mathrm{DM}$ for the soil from plots supplemented using G1 with M2 grass mixture to $0.55 \% \mathrm{DM}$ for the $\mathrm{SS} 2$ and $\mathrm{M} 1$ grass mixture, whereas the average $\mathrm{N}$ content in the soil collected in October was lower than in July and the highest content was recorded in SS2 with M2 $(0.36 \% \mathrm{DM})$ whereas the lowest - in G1 with M1 (0.18\% DM) (Figure $1 \mathrm{E}-\mathrm{F})$.

The average content of available phosphorus in soil was presented in Figures 1 G-H. The values of this parameter obtained for the samples collected in July ranged from 20.06 to $67.93 \mathrm{mg}$ $\mathrm{P}_{2} \mathrm{O}_{5} / 100 \mathrm{~g}$ DM for SS1 soil treatment with M2 grass mixture and G1 with M1, respectively. In the second time of sampling the highest average content of $\mathrm{N}$ in soil was recorded in $\mathrm{G} 2$ with M1 (60.57 $\mathrm{mg} \mathrm{P}_{2} \mathrm{O}_{5} / 100 \mathrm{~g} \mathrm{DM}$ ), while the lowest in control with $\mathrm{M} 2\left(20.58 \mathrm{mg} \mathrm{P}_{2} \mathrm{O}_{5} / 100 \mathrm{~g} \mathrm{DM}\right)$. Generally, higher average content of available $\mathrm{P}$ was recorded in the soil amended with "Granbial" fertilizer, compared to all other treatments.

Sewage sludge soil treatment modifies its chemical and biological properties, which was described in the literature data [Siuta 2003, Singh and Agrawal 2008, Napora and Grobelak 2014]. The changes were related to the sewage sludge origin, treatment processes and composition [Singh and Agrawal 2008, Mohamed et al. 2018]. Concerning the soil nutrients content, our results reveal that TOC and available $\mathrm{P}$ increased after dewatered sewage sludge and "Granbial" application, but in the case of SS such increase was observed only in July. The differences between the effects of studied substrates can be caused by varying the rate of the raw and thermally treatment sewage sludge mineralization. Wiater et al. [2003] reported that thermally dried granular sewage sludge mineralization occurs with lesser intensity than in the unprocessed sludge. According to Mohamed et al. [2018], forest soil fertilization with sewage sludge significantly influenced only the increase in the total phosphorus content. In the study of Kitczak and Czyż [2009], amendment of sandy soil with sew-

Table 4. Soil granulometric composition in control (C), soil treatments with 14.5 and 29 t DM/ha sewage sludge (SS1 and SS2, respectively) and 14.5 and 29 t DM/ha "Granbial" fertilizer (G1 and G2, respectively)

\begin{tabular}{|c|c|c|c|c|}
\hline Treatment & Statistics & Sand [\%] & Silt [\%] & Clay [\%] \\
\hline \multirow{2}{*}{ C } & mean & 65 & 26 & 9 \\
\hline & range & $53-74$ & $21-35$ & $5-13$ \\
\hline \multirow{2}{*}{ SS1 } & mean & 62 & 28 & 11 \\
\hline & range & $57-68$ & $23-32$ & $9-11$ \\
\hline \multirow{2}{*}{ SS2 } & mean & 61 & 28 & 11 \\
\hline & range & $56-65$ & $26-31$ & $9-14$ \\
\hline \multirow{2}{*}{ G1 } & mean & 68 & 27 & 6 \\
\hline & range & $67-69$ & $25-28$ & $5-6$ \\
\hline \multirow{2}{*}{ G2 } & mean & 68 & 27 & 6 \\
\hline & range & $61-70$ & $25-32$ & $5-6$ \\
\hline
\end{tabular}



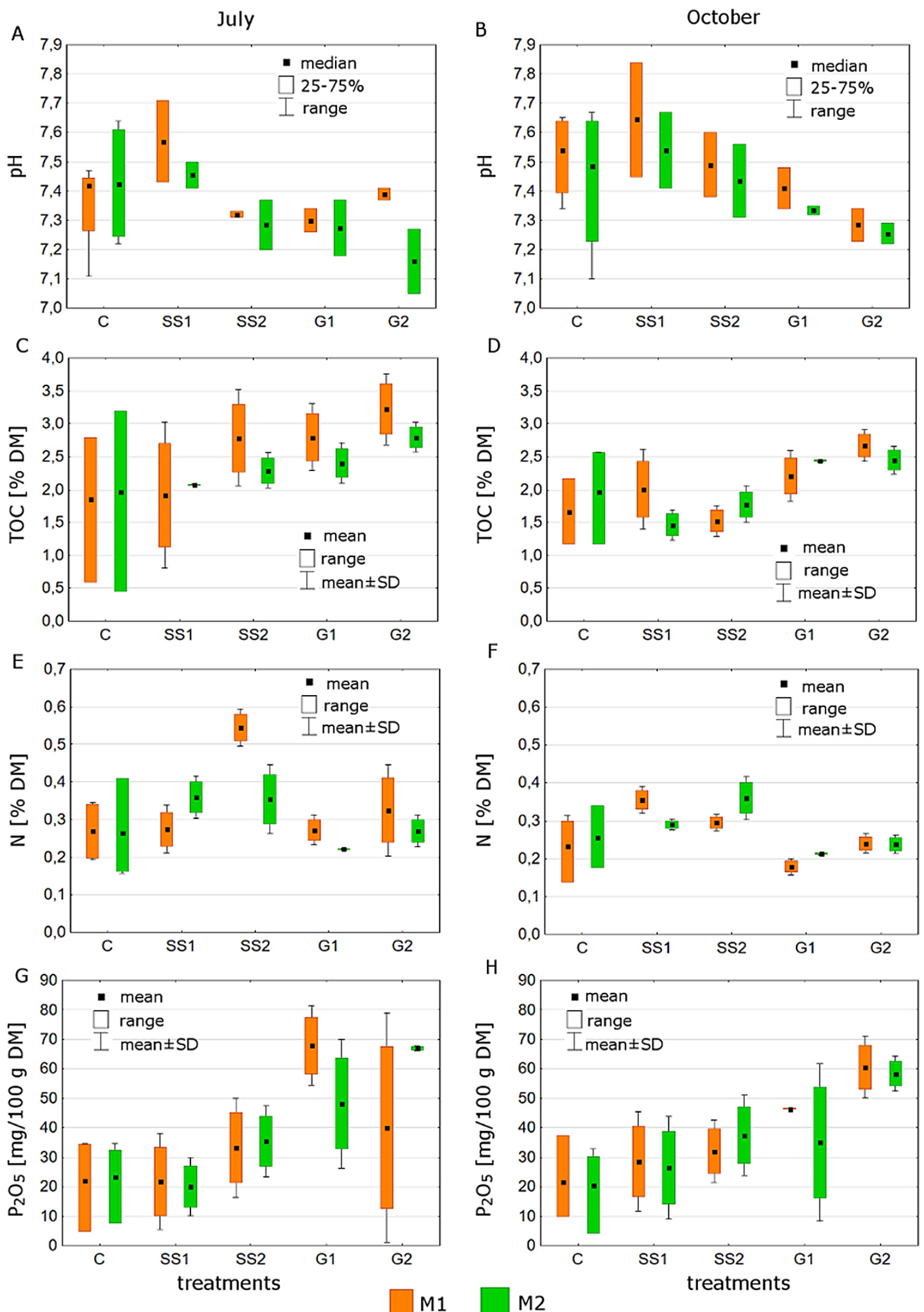

Figure 1. Selected physico-chemical parameters of soil in control plots (C), treated with 14.5 and $29 \mathrm{t} \mathrm{DM} / \mathrm{ha}$ mechanical dewatered sewage sludge (SS1 and SS2, respectively) and 14.5 and 29 t DM/ha "Granbial" fertilizer (G1 and G2, respectively) and lawn grass mixtures of Eko (M1) and Roadside (M2) measured in July (2011 and 2015) and October (2011 and 2015) (SD - standard deviation) 
age sludge in a plot experiment caused an increase of organic matter (by $40 \%$ ), total nitrogen (from 0.1 to $0.4 \%$ ) and phosphorus content (from 0.1 to 0.5\%). Marando et al. [2011] conducted research in lysimetric experiment where they applied various types of sewage sludge (composed and thermally dried sludge at $80-90^{\circ} \mathrm{C}$ ) for the reclamation of a soil from a working limestone quarry, situated in Spain. After 13 months of sludge addition, they observed a significant increase in $\mathrm{C}$ (from 0.5 to $1.7 \%$ and from 0.5 and $1.9 \%$ for composted and dried sludge, respectively) and in $\mathrm{N}$ content (from 0.07 to $0.14 \%$ and from 0.07 to $0.11 \%$ for composted and dried sludge, respectively). Moreover, the authors stated that application of composted sludge to soil resulted in much slower decomposition, compared to thermally dried sludge. Generally, in our study higher TOC, N and P contents for dewatered sewage sludge (SS) were obtained in the samples collected in July, while higher available $\mathrm{P}$ content for the samples with "Granbial" in October, as compared to the control and SS. In the case of TOC and N in soils treatment with G1 and G2, the average level of these parameters was stable during the period of study.

The impact of the experimental factors on the average number of amylolytic bacteria in the rhizosphere zone is presented in Figures 2 A-B. In this study, the grass mixture did not have significant effect on this parameter (Figure $2 \mathrm{~A}$ ). The average total count of the studied bacteria was varied and the smallest value was recorded in the control plots with M1 $\left(7.8 \times 10^{6} \mathrm{cfu} / \mathrm{g} \mathrm{DM}\right.$ of roots and soil), while the largest was observed in the samples from plots G2 with M2 $\left(7.8 \times 10^{6}\right.$ $\mathrm{cfu} / \mathrm{g}$ DM of roots and soil).

There were significant differences in the average number of amylolytic bacteria connected with treatments and sampling time (Figure 2 B). The highest average number of these bacteria was found for the samples collected in October from G2 ( $44.6 \times 10^{6} \mathrm{cfu} / \mathrm{g} \mathrm{DM}$ of roots and soil), whereas the lowest results were obtained for the samples taken in October from SS1 $\left(2.5 \times 10^{6} \mathrm{cfu} / \mathrm{g}\right.$ DM of roots and soil). The average number of amylolytic bacteria was significantly higher in the samples taken in October from plots treated with "Granbial" (G1 and G2) as compared to the control and soil with sewage sludge. It should be mentioned that the average number of the studied bacteria from $\mathrm{SS} 1$ and SS2 in July was higher (by about 500\%) than in October, but these differences were not statistically significant. In the case of the soils treated with G1 and G2, this microbiological parameter was significantly higher in October as compared to July.

We found that the grass mixture with treatment did not significantly influence the amylases activity in soil (Figure 3A). The average amylases activity ranged from 1.3 to $2.2 \mathrm{mg} \mathrm{Glc} /(\mathrm{g} \mathrm{DM} \cdot 24 \mathrm{~h})$ for control with M1 and G2 with M1, respectively. The activity of the studied enzymes differed significantly depending on the treatment and sampling time (Figure 3B). The average activity of amylases in the soil samples collected in July was the lowest in the control $(1.5 \mathrm{mg} \mathrm{Glc} /(\mathrm{g} \mathrm{DM} \cdot 24 \mathrm{~h}))$, whereas the highest in G2 (2.2 mg Glc/(g DM · $24 \mathrm{~h}))$. Sig-
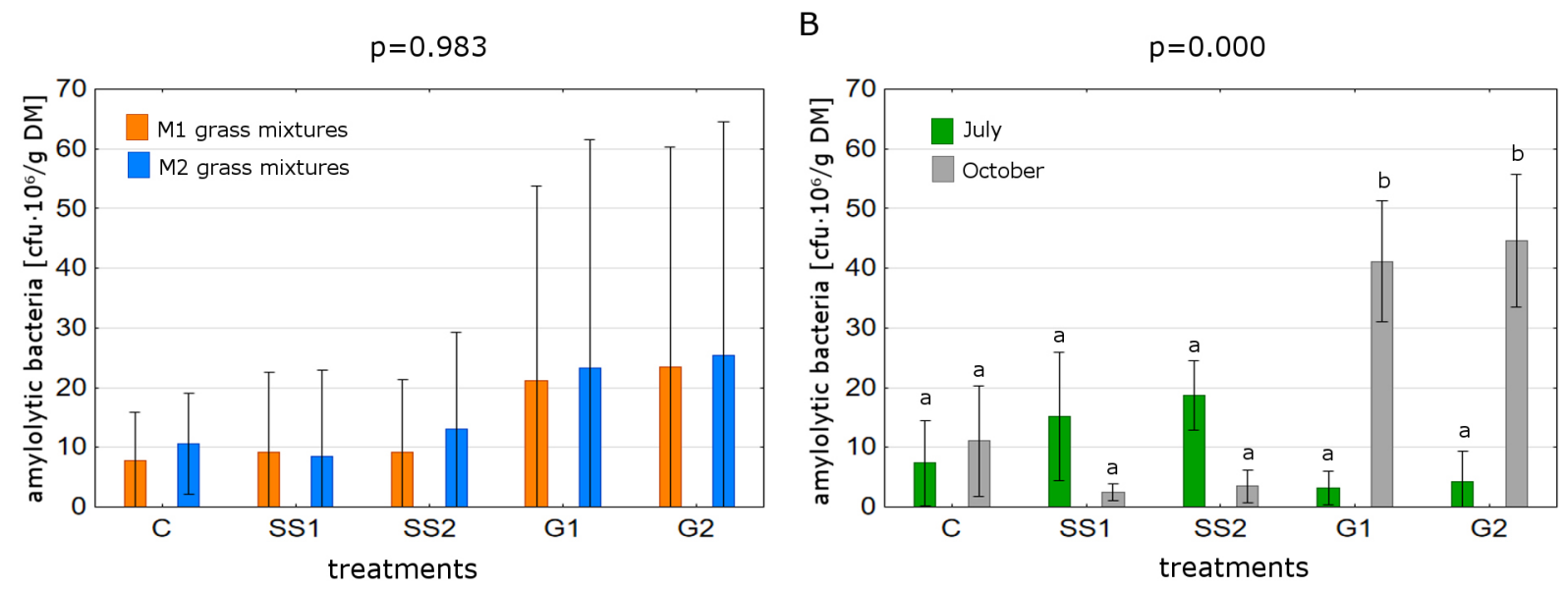

Figure 2. The average number of amylolytic bacteria in grass mixtures (M1 - Eko and M2 - Roadside) rhizosphere in samples collected in July and October from control plots (C), treated with sewage sludge in dose of 14.5 and 29 t DM/ha (SS1 and SS2, respectively) and "Granbial" fertilizer in dose of 14.5 and 29 t DM/ha (G1 and G2, respectively) (different letters for columns indicate significant differences between means for each treatment and grass mixture (A), treatment and sampling time (B), where $p<0.05$, assessment on Tukey's test for $\alpha=0,05$; the error bars represent $5 \%$ confidence interval) 

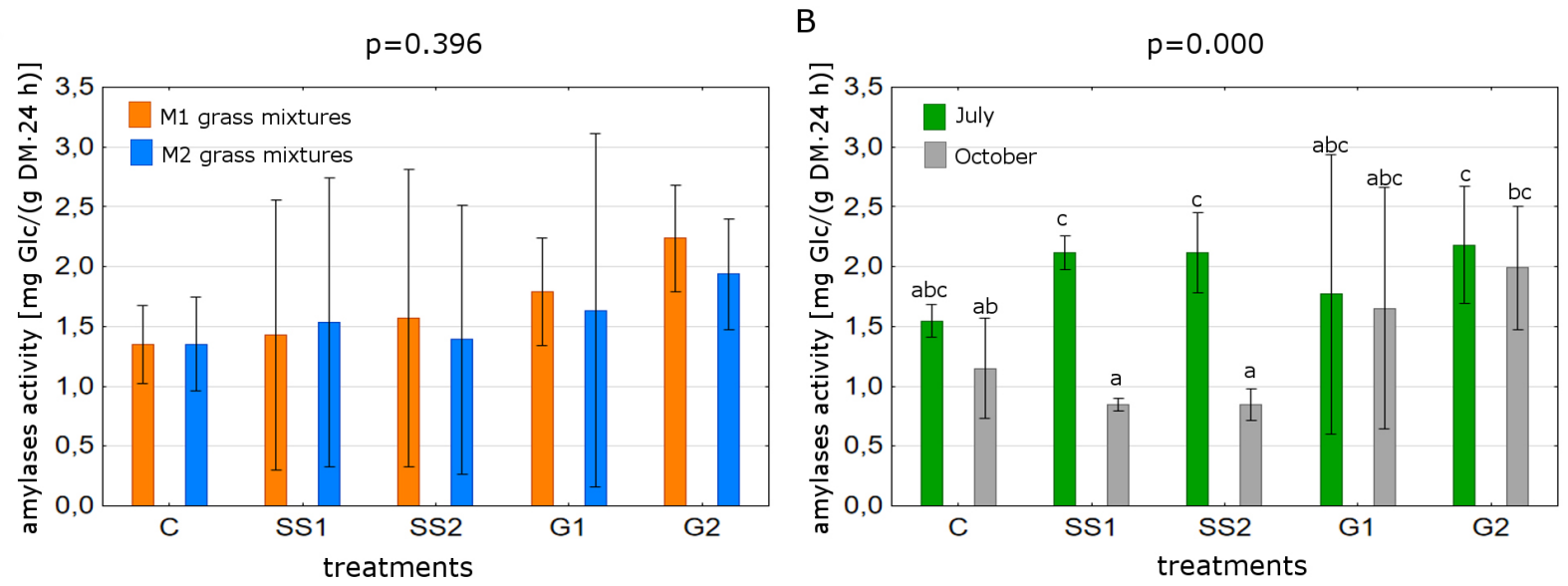

Figure 3. The average amylases soil activity in soil samples with grass mixtures (M1 - Eko and M2 - Roadside) collected in July and October from control plots (C), treated with sewage sludge in dose of 14.5 and $29 \mathrm{t} \mathrm{DM} / \mathrm{ha}$ (SS1 and SS2, respectively) and "Granbial" fertilizer in dose of 14.5 and 29 t DM/ha (G1 and G2, respectively) (different letters for columns represent significant differences between means for each treatment and grass mixture (A), treatment and sampling time (B), where $\mathrm{p}<0.05$, assessment on Tukey's test for $\alpha=0,05$; the error bars represent $5 \%$ confidence interval)

nificantly higher soil amylases activity in SS1, SS2 and G2 as compared to the control was observed. The results obtained in the second date of sampling (in October) ranged from 0.8 to $2.0 \mathrm{mg} \mathrm{Glc} /(\mathrm{g} \mathrm{DM}$ - $24 \mathrm{~h}$ ) for SS and G2, respectively. It should be mentioned that the activity of these enzymes activity in SS1 and SS2 significantly decreased in October, approximately being halved as compared to July, while the soil amylases activity in G2 and G2 was at a similar level.

The correlation analysis presented in Table 5 showed significant negative relationships between the soil amylases activity and the $\mathrm{pH}$ measured in $\mathrm{H}_{2} \mathrm{O}(\mathrm{r}=-0.43)$. The content of clay also negatively correlated with the analyzed enzymes activity $(\mathrm{r}=-0.41)$. A positive correlation between the soil amylases activity and selected characteristics of soil such as total organic carbon content (TOC), available $\mathrm{P}$ and sand content, was observed. The correlation coefficients ( $\mathrm{r}$ ) for these relationships were: $0.53,0.34,0.30$, respectively. The amylases activity of soil is connected with the amount of amylolytic bacteria in soil, as indicated by the positive significant correlation coefficient $(\mathrm{r}=0.33)$.
The amylolytic activity in soil is an important part of carbon and energy circulation in the environment. In our study, the application of raw and thermally processed sewage sludge to soil intensified the activity of bacteria and starch decomposing enzymes. The literature data indicate that sewage sludge addition stimulated the growth of microorganisms and changed the enzymes activity. A direction and intensity of the modification depends on type of substrates, dose and studied enzymes [Napora and Grobelak 2014]. In addition, the microbial activity of soil is related to other factors i.e. soil $\mathrm{pH}$, moisture, soil temperatures, content of major nutrient in soil, air temperatures and precipitation [Galus-Barchan and Paśmionka 2014].

In our study, a significant negative correlation between $\mathrm{pH}$ and amylases activity was obtained. The soil $\mathrm{pH}$ is important parameter, which decides about soil biological processes, ability of microorganisms for growth, availability of nutrients and contaminants [Su et al. 2004 and Rousk et al. 2009]. As reported by Galus-Barchan and Paśmionka [2014], bacteria best tolerate the soil $\mathrm{pH}$ ranging from 6.5 to 7.5 ; therefore, the high alkalinity of soil

Table 5. The correlation coefficients between selected physicochemical properties of soil and biological parameters

\begin{tabular}{|c|c|c|c|c|c|c|c|c|c|}
\hline Variables & $\mathrm{pH} \mathrm{in} \mathrm{H}_{2} \mathrm{O}$ & $\mathrm{TOC}$ & $\mathrm{N}$ & $\mathrm{P}_{\text {avalable }}$ & Sand & Silt & Clay & $\begin{array}{c}\text { Amylolytic } \\
\text { bacteria }\end{array}$ & $\begin{array}{c}\text { Amylases } \\
\text { activity }\end{array}$ \\
\hline $\begin{array}{c}\text { Amylolytic } \\
\text { bacteria }\end{array}$ & -0.21 & 0.15 & $-0,28$ & 0.24 & 0.25 & $-0,13$ & $\mathbf{- 0 . 3 0 ^ { * }}$ & - & $\mathbf{0 . 3 3}^{*}$ \\
\hline $\begin{array}{c}\text { Amylase } \\
\text { activity }\end{array}$ & $-\mathbf{0 . 4 3 ^ { * }}$ & $\mathbf{\mathbf { 0 . 5 3 } ^ { * }}$ & 0.03 & $\mathbf{0 . 3 4 ^ { * }}$ & $\mathbf{0 . 3 0 ^ { * }}$ & -0.11 & $\mathbf{- 0 . 4 1 ^ { * }}$ & $\mathbf{0 . 3 3}^{*}$ & - \\
\hline
\end{tabular}

* significant correlation coefficients for $\mathrm{p}<0.05$ 
can inhibit the growth and activity of amylolytic bacteria. In the present study, a positive significant correlation between TOC and amylses activity was obtained, while no significant correlation between the number of amylolytic bacteria and TOC was found. According to Jorge-Mardomingo et al. [2013], microorganisms can behave differently in the soil amended with sewage sludge. The application of a very high dose of sludge may decrease the number of bacteria. It depends on the efficiency of using $\mathrm{C}$ from biosolids by microorganisms and the amount of labile and mineralizable fraction of organic matter in mix of soil-sludge. Moreover, the native microorganisms can be better adapted in the soil with lower amount of carbon, while a high dose of organic substrate may cause stress.

Jurkowski and Błaszczyk [2012] indicate that the highest growth of individual groups of microorganisms is at specific temperature and humidity where metabolic processes are the most efficient. In our study, the activity of amylolytic microorganisms in connection with sewage sludge treatment was varied, depending on the vegetation period. The air temperatures and rainfall as well as the type of sewage sludge can modify the number of bacteria and enzymes activity. Walczak et al. [2013] indicated that the air temperature regulates the biological activities of bacteria. However, too high temperature may inhibit the growth and cause cells damage. The water is also an important factor for the number and activity of bacteria and their growth is inhibited when the soil water content is less than $30 \%$. The microorganisms are sensitive to the soil drought, even small amount of water below the optimal value results in an inhibition of their development.

The amylolitic activity may depend on the contaminants transport such as heavy metals and organic pollutants. Some metals e.g. As, $\mathrm{Cd}, \mathrm{Hg}$, have a strong bactericidal effect on the microbial growth, even at minimal concentration. However, the availability of micro- and macroelements from the amended soil is a function of the climatic conditions during the growing season, dose of sewage sludge and ratio of carbon and nitrogen [Gondek 2012].

In sum, the soil in urbanized areas is characterized by specific habitat conditions for microorganisms. As reported by Frączak [2010] and Tyszkiewicz [2014] any changes in soil properties influenced the biotic relation between microorganisms. Therefore, soil microbes and the enzymes activity are considered to be the most susceptible to the change of environmental parameters.

\section{CONCLUSIONS}

1. Supplementation of the studied soils with raw and thermally dried sewage sludge caused changes in the soil $\mathrm{pH}, \mathrm{TOC}$, available $\mathrm{P}$ and total $\mathrm{N}$ content. Higher values of TOC, total $\mathrm{N}$ and available $\mathrm{P}$ in soil with mechanical dewatered sewage sludge were observed in July, while the increase of available $\mathrm{P}$ in soil with thermally processed sludge was found in October.

2. The grass mixture did not have a significant effect on the number of amylolytic bacteria and amylases activity in the studied soils.

3. The time of sampling significantly influenced the number of amylolytic bacteria and amylases activity the in soil. In the case of the soil with dewatered sewage sludge, the significantly higher amylolytic activity was found in July, whereas in the soil with thermally dried sludge, these parameters were higher in October.

4. A significant negative correlation between the amylases activity and soil $\mathrm{pH}$ and positive correlation between TOC, P-available, sand content and amylases activity were found. The number of amylolytic bacteria was positively correlated with the sand content and amylases activity.

\section{Acknowledgement}

The research was financially supported by the Polish Ministry of Science and Higher Education, projects number MB/WBiIŚ/14/2017 and S/ WBiIŚ/3/2015.

\section{REFERENCES}

1. Bach A., Frazik-Adamczyk M. 2006. Charakterystyka zagrożeń zieleni miejskiej ze szczególnym uwzględnieniem zieleni $\mathrm{w}$ ciągach komunikacyjnych. Opracowanie wykonane dla Urzędu Miasta Krakowa, Wydział Gospodarki Komunalnej i Ochrony Środowiska, Kraków.

2. Bourioug M., Girardclos O., Gillet F. AlaouiSehmer L., Pascale B.,Alaoui-Sossé B., Aleya L. 2018. Sewage sludge as a soil amendment in a Larix decidua plantation: Effects on tree growth and floristic diversity. Science of The Total Environment, 621, 291-301.

3. Frączek K. 2010. Skład mikrobiocenotyczny drobnoustrojów biorących udział $\mathrm{w}$ procesach przemian azotu w glebie w otoczeniu składowiska odpadów komunalnych. Woda-środowisko-Obszary Wiejskie, 10 (2), 61-71.

4. Galus-Barchan A, Paśmionka I. 2014. 
Występowanie wybranych mikroorganizmów w glebie na obszarze Puszczy Niepołomickiej ze szczególnym uwzględnieniem grzybów pleśniowych. Polish Journal of Agronomy, 17, 11-17.

5. Gondek K. 2012. Wpływ nawożenia nawozami mineralnymi, obornikiem od trzody chlewnej i komunalnymi osadami ściekowymi na plon i niektóre wskaźniki jakości ziarna pszenicy jarej (Triticum aestivum 1.). Acta Agrophysica, 19(2), 289-302.

6. Greinert A. 2000. Ochrona i rekultywacja terenów zurbanizowanych. Wyd. Politechniki Zielonogórskiej, Monografia, Zielona Góra.

7. Jezierska-Tyś S., Frąc M. 2008. Effect of sewage sludge on selected microbiological and biochemical indices of soil fertility in view of domestic and world wide studies: a review. Acta Agrophysica, 12(2), 393-407.

8. Joniec J., Furczak J. 2007. Liczebność wybranych grup drobnoustrojów w glebie bielicowej pod uprawą wierzby użyźnionej osadem ściekowym po drugim roku jego działania. Annales Universitatis Mariae Curie-Skłodowska Sec. E Agricultura, 62, 1, 93-104.

9. Jorge-Mardomingo I., Solver-Rovira P., Casermeiro M.A., de la Cruz M.T., Polo A. 2013. Seasonal changes in microbial activity in a semiarid soil after application of a high dose of different organic amendments. Geoderma, 206, 40-48.

10. Jurkowski M., Błaszczyk M. 2012. Charakterystyka fizjologiczno-biochemiczna bakterii fermentacji mlekowej. Kosmos. Problemy nauk biologicznych, 61(3), 493-504.

11. Kitczak T., Czyż H. 2009. Przydatność osadów komunalnych i mieszanek trawnikowych do zadarniania gruntów bezglebowych. Rocznik Ochrona Środowiska, 11, 465-472.

12. Kucharski J., Wyszkowska J., Nowak G., Harms H. 2000. Activity of enzymes in soil treated with sewage sludge. Polish Journal of Soil Science, 33 (1), 29-32.

13. Marando G., Jiménez P., Hereter A., Julià M., Ginovart M., Bonmati M. 2011. Effects of thermally dried and composted sewage sludges on the fertility of residual soils from limestone quarries. Applied Soil Ecology, 49, 234-241.

14. Napora A., Grobelak A. 2014. Wpływ osadów ściekowych na aktywność mikrobiologiczną i biochemiczną gleby. Inżynieria i Ochrona Środowiska, 4, 619-630.

15. Niedbała M., Smolińska B., Król K. 2010. Zanieczyszczenia gleb miejskich miasta Łodzi wybranymi pierwiastkami śladowymi. Zeszyty Naukowe Politechniki Łódzkiej. Chemia Spożywcza i Biotechnologia, 74, 29-38.

16. Rodina A. 1968. Mikrobiologiczne metody badania wód. Państwowe Wydawnictwo Rolnicze i Leśne, Warszawa.
17. Rousk J., Brookes P.C., Baath E. 2010. Investigating the mechanisms for the opposing $\mathrm{pH}$ relationships of fungal and bacterial growth in soil. Soil Biology \& Biochemistry, 42, 926-934.

18. Rozporządzenie Ministra Środowiska z dnia 6 lutego 2015 r w sprawie komunalnych osadów ściekowych (Dz.U. 2015 poz. 257).

19. Sanchez-Monedero M.A., Mondini C., de Nobili M., Leita L., Roig A. 2004. Land application of biosolids. Soil response to different stabilization degree of the treated organic matter. Waste Management, 24, 325-332.

20. Schinner F., Mersi von W. 1990. Xylanase-, CMcellulase- and invertase activity in soil, an improved method. Soil Biology and Biochemistry, 22, 511-515

21. Singh R.P., Agrawal M. 2008. Potential benefits and risks of land application of sewage sludge. Waste Management, 28, 347-358.

22. Siuta J. 2003. Uwarunkowania i sposoby przyrodniczego użytkowania osadów ściekowych. Inżynieria Ekologiczna, 9, 7-42.

23. Su D.C., Wong J.W.C., Jagadeesan H. 2004. Implication of rhizospheric heavy metals and nutrients for the growth of alfalfa in sludge amended soil. Chemosphere, 56, 957-965.

24. Szymków J., Świtecka M. 2013. Granulacja zhigienizowanych osadów ściekowych. Inżynieria i Aparatura Chemiczna, 3, 262-263.

25. Tyszkiewicz Z. 2014. Zróżnicowanie zbiorowisk grzybów wybranych gleb odwodnionych siedlisk bagiennych $\mathrm{w}$ dolinie rzeki Biebrzy. Inżynieria Ekologiczna, 40, 55-64.

26. Walczak M., Burkowska A., Brzezinska M., Kalwasińska A. 2013. Podstawy mikrobiologii w teorii i praktyce. Wydawnictwo Naukowe Uniwersytetu Mikołaja Kopernika w Toruniu, Toruń.

27. Wiater, J. Łukowski, A. Fitko, H., Stelmach, S., Sobolewski, A., Figa, J. 2003. Wstępne badania aplikacyjne granulowanych nawozów organicznomineralnych na bazie osadów ściekowych. Zeszyty Naukowe Politechniki Białostockiej. Inżynieria Środowiska, 16(2), 233-237.

28. Wolińska A. 2010. Aktywność dehydrogenazowa mikroorganizmów glebowych i dostępność tlenu w procesie reoksydacji wybranych mineralnych gleb Polski. Acta Agrophysica, 180(3), Rozprawy i Monografie.

29. Wolski K., Kotecki A., Spik Z., Chodak T., Bujak H. 2006. Ocena wstępna możliwości wykorzystania kilkunastu gatunków traw w stabilizacji skarp obwałowań składowiska „Żelazny Most” w Rudnej. Zeszyty Naukowe Uniwersytetu Przyrodniczego we Wrocławiu, Rolnictwo, 545, 293-299.

30. Wysocki C., Stawicka J. 2005. Trawy na terenach zurbanizowanych. Łąkarstwo w Polsce, 8, 227-236. 